\title{
"The Light of Aceh" Branding Strategy through E-Tourism on Sustainable Tourism Development in Aceh Province
}

\author{
Khalida Ulfa ${ }^{1}$, Muchamad Zaenuri ${ }^{2}$, Dian Eka Rahmawati ${ }^{3}$, Saddam Rassanjani ${ }^{4}$, Mukhrijal ${ }^{5}$, Ayu \\ Imanullah 6 \\ ${ }^{1}$ Master of Government Affairs and Administration, Universitas Muhammadiyah Yogyakarta, Indonesia \\ 2,3 Department of Government Affairs and Administration, Universitas Muhammadiyah Yogyakarta, Indonesia \\ 4,5Universitas Syiah Kuala, Jl. Teuku Nyak Arief No.441, Kopelma Darussalam, Syiah Kuala, Banda Aceh City, Aceh, Indonesia \\ Indonesia \\ ${ }^{6}$ Master of Public Administration, Universitas Malikussaleh, Lhokseumawe, Aceh, Indonesia \\ Corresponding Author: khalida.ulfa.psc19@mail.umy.ac.id \\ doi) https://doi.org/10.18196/jgpp.v8i3.11034
}

Article Info

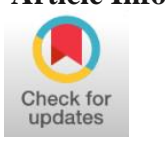

Article History;

Received:

2021-02-01

Revised:

2021-03-01

Accepted:

2021-06-20

\begin{abstract}
One of the latest strategies in Indonesia in developing tourism is ETourism, a digital platform that provides convenience for foreign and domestic tourists. This study aims to determine the Branding Strategy "The Light of Aceh" through E-Tourism in Sustainable Tourism Development in Aceh Province and its inhibiting factors. The research method used descriptive qualitative. The research data came from primary and secondary data related to the research focus. The data analysis technique used the Nvivo 12 plus analysis with crosstab through the chart and sociogram features. The results showed that the Branding strategy "The Light of Aceh" through E-Tourism in sustainable tourism development used four strategies: POSE (Paid Media, Owned Media, Social Media, and Endorser). Of the four strategies, the highest percentage is through social media digital platforms which are the most strategic in promoting tourism. The inhibiting factor is in terms of human resources that are still minimal, in terms of infrastructure that has not been managed properly in several tourist destinations. The community's social conditions are still minimal related to public awareness of managing tourist destination places properly. Hence, it is critical to support tourism actors to return or whether or not to Aceh for a tour
\end{abstract}

Keyword: Branding "The Light Of Aceh"; E-Tourism; Sustainable of Development.

\section{INTRODUCTION}

The latest strategy in Indonesia for tourism development is through information technology. Information technology is the latest breakthrough in Indonesia for developing sustainable tourism. With better technological sophistication, the area should easily promote its tourism through E-Tourism, a digital platform convenient for foreign and domestic tourists. Indonesia has great potential in its tourism from its marine tourism, culture, history, culinary, and others. This strategy is also good for supporting the people's welfare so that every foreign and domestic citizen who comes to visit Indonesia will discover various interesting tourism in Indonesia, for example, tourism in Aceh Province. The concept of sustainable development remains the best development principle often used, one of which is a guide in tourism development.

The development of tourism has an important role in economic, social and environmental aspects. From the economic aspect, the tourism sector contributes foreign exchange from foreign tourist visits (tourists) and Gross Regional Domestic Product (GRDP) and its components (Zaenuri et al., 2019). Development planning with a sustainable concept is needed in the area to boost the community's economic growth. E-Tourism describes the digitization, optimization and 
effectiveness of the information flow process related to tourism. Travelers need information before travel to help them plan and choose between promotional options and travel packages to learn better about the area (Datya, 2019).

In web-based E-Tourism services, the complexity of choosing diverse tourism products, travel routes, transportation models, timing and lodging accommodations makes the availability of accurate, current and relevant information for the efficient operation of the tourism industry (Bhatta \& Ohe, 2019). However, some tourists plan their tourist destinations, usually based on satisfaction and are more economical. For tourists who plan their tourist destinations, it takes more time to collect information about tourist destinations than tourists who use the services of travel agents (Rizki Wahyudi, Ema Utami, 2016).

The Aceh Culture and Tourism Office (Disbudpar) initiated the formation of Aceh Digital Tourism. The goal is to promote Aceh tourism to the outside world using digital media platforms. Disbudpar will increase the use of digital media as a platform to drive tourism promotion. The collaboration of the Government of Aceh, in this case, Disbudpar with the digital creative industry community, is by presenting integrated information management and tourism promotion and has a wider impact based on digital platforms (https://www.ajnn.net/news/gagas-aceh-digital tourism-disbudpar-aceh-collaboration-with-startup-content-creator/index.html).

Through "The Light of Aceh", the Aceh government is working together to promote tourism. "The Light of Aceh" conveys enthusiasm for all people united through the Islamic Shari'a Rahmatan lil' alamiin as a bright light that invites the values of goodness. It is a joint movement to build the Aceh tourism industry through the spirit. Then, as a co-branding of national tourism, called Wonderful Indonesia, it becomes an identity and pride for the people of Aceh. Meanwhile, the Head of Marketing for Aceh's Disbudpar, Rahmadhani, said, "The Light of Aceh" tourism branding is not only known by Banda Aceh residents or Aceh tourism actors but also comes to remote districts/cities through event performances, such as the 2019 Saman Festival (http://www.ajnn.net/news/Branding-the-light-of-aceh-dikampanyekan-via-festival samangayo-lues/index.html).

The magnitude of Indonesia's tourism potential will provide great benefits for the welfare of society and progress for Indonesia. With the state's foreign exchange earnings in 2017, the tourism sector has occupied the second-highest position, with total revenues reaching Rp. 202 trillion, an increase of $12 \%$ from 2016. Realizing the huge tourism potential, the government has targeted by 2020 to become the core economy of Indonesia and the largest foreign exchange earner for the country. Various efforts continue to be made for the development of the tourism sector. Starting from developing new tourist destinations, national strategic projects, support for tourism development in the region and various other development strategies. Many local governments have made the tourism sector the leading economic development sector and improved the people's welfare. Through 3 flagship programs, creative Aceh, rich Aceh and Aceh Meuadab, the Aceh government has a high commitment to making the tourism sector and creative economy the leading sector to achieve the vision of a great Aceh. The development of tourism has shown a positive trend seen from the increasing number of tourist visits to Aceh, both domestic and foreign tourists with a longer length of stay. In 2018, 2.5 million people visited Aceh, about 20 percent higher than the previous year. In 2019, 3 million tourists visited Aceh. At the moment, new destinations are also growing in Aceh, supported by the tourism industry and the organization of national and international events (disbudpar.acehprov). 


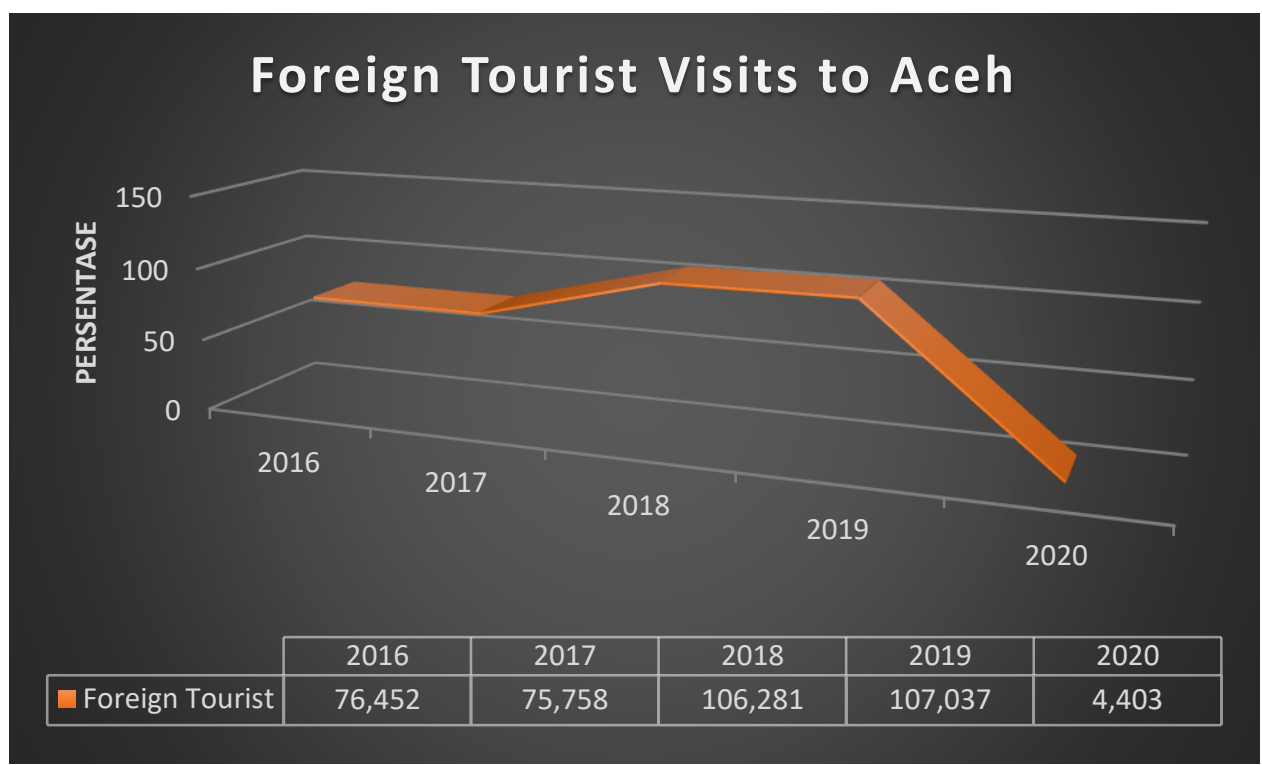

Figure 1. Foreign Tourist Visits to Aceh

Source: Aceh Province Culture and Tourism Office, (processed by the researchers, 2020)

Figure 1. shows the number of foreign tourist visits or foreign tourists to Aceh from 2016 to 2019 has increased quite well for the country's foreign exchange. In 2016, 76,452 tourists visited Aceh, but in the following year, 2017, the number decreased to $1 \%$ or 75,758 tourists. In 2018 , foreign tourists increased to $40 \%$ or 106,281 visiting Aceh, while in 2019, there was a slight increase of 107,037 foreign tourists. In 2020, it decreased by 96 percent due to a pandemic from Wuhan, China, so the Indonesian government, especially in Aceh, closed the entrance of foreign tourists to Aceh.

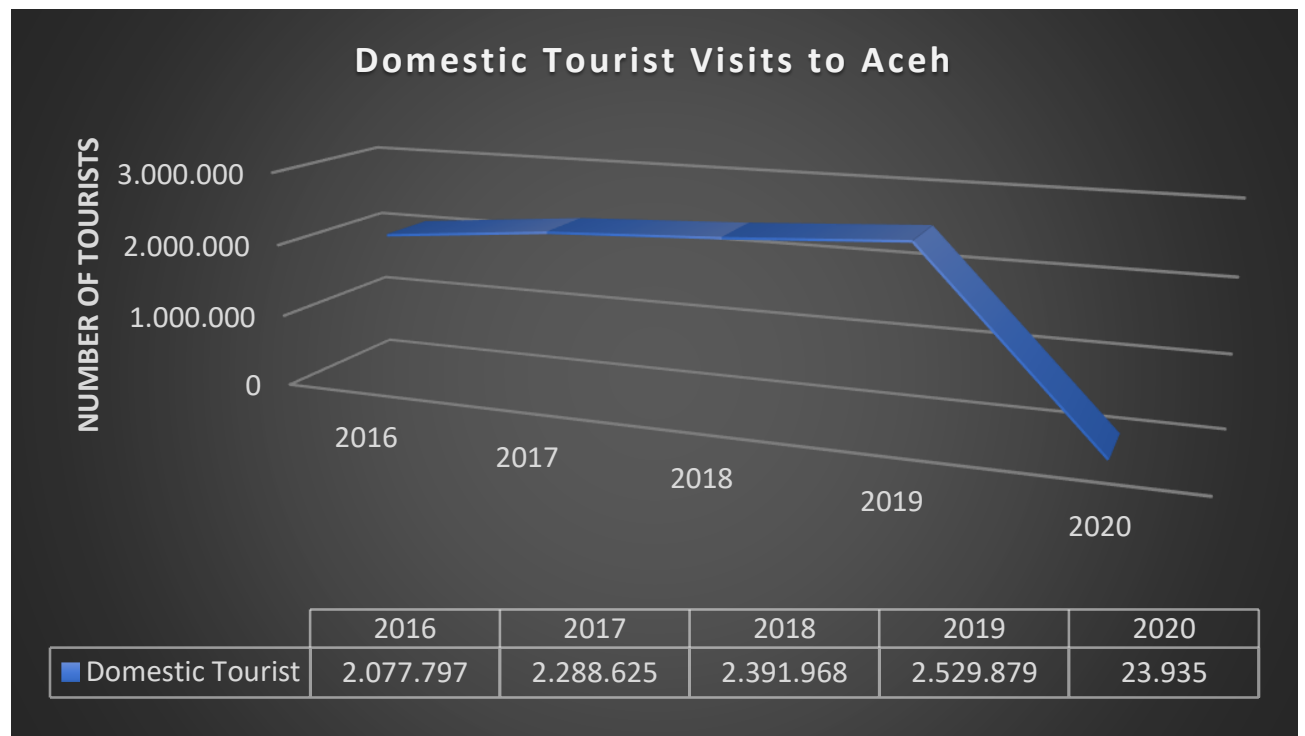

Figure 2. Domestic Tourist Visits to Aceh

Source: Aceh Province Culture and Tourism Office, (processed by the researchers, 2020)

Figure 2. explains that Domestic tourists entering Aceh Province in 2016 were 2,077,797 people, and in 2017 there was an increase of 22 percent or 2,288,625 people. In 2018, 2,391,968 people visited Aceh while, in 2019, it also increased by 14 percent to 2,529,879. In 2020, tourists decreased significantly due to the coronavirus outbreak originating from China, precisely in an 
animal market in Wuhan, and the Indonesian state, especially the Aceh Province, for several months. In 2020, after the new normal, domestic tourists greatly decreased by $98 \%$ from the previous year, which amounted to 23,935 people.

Regulations on tourism in Aceh Province exists in the Aceh Qanun Chapter V research and development of tourism and Chapter VIII on tourism marketing and promotion, Following up on the Vision of the Aceh Government for 2012-2017, "A dignified, prosperous, just and independent Aceh based on the UUPA as a form of the Helsinki MoU." There are 3 (three) priority programs out of 10 (ten) Aceh Development Priority Programs in the culture and tourism towards a dignified, prosperous, just and independent Acehnese society: Dinul Islam Adat and Culture, Food Security and Value-Added Products and Poverty Reduction. To achieve the success of these priorities, the Aceh government, through the support of all parties, needs to accelerate the cultural and economic development of Aceh through strengthening cultural values and developing the tourism industry, which is supported by the diversity of Acehnese arts and culture, natural beauty and Tsunami heritage guided by tourism and the principles and values of Dinul Islam. Culture and tourism are part of regional development and character-building towards an independent, advanced, just, prosperous and civilized society. Cultural and tourism development is also a series of sustainable development efforts covering all aspects of people's lives, including religious, economic, educational, social, and cultural (disbudpar.acehprov).

In cultural development, creating conditions for people who have a noble character, morality, and ethics is vital to create an atmosphere of community life full of tolerance, tolerance, and harmony. Through awareness of culture, it is also expected to provide direction for the realization of national identity following the noble values of the nation's culture in creating a conducive and peaceful climate so that the values of local wisdom can respond positively to the challenges and impacts of modernization following the values and the spirit of nationality. The Aceh government continues to make various efforts to protect, foster and develop Acehnese culture and arts to create an Acehnese people who have a noble character, morality, ethics, culture, and civility and have high competitiveness towards a prosperous, just and prosperous society following the philosophy of life and Acehnese Islamic cultural values (disbudpar.acehprov).

However, tourism development in Aceh is still faced with challenges. Such as in terms of development, character development and quality of human resources, perceptions of security issues in Aceh, planning systems and budget priorities, development of leading tourist destinations and events, growth and support for the tourism industry as well as the direction of Aceh tourism development which is still a serious concern for stakeholders' interest. Therefore, to overcome these challenges, the Aceh government wants to work together with all stakeholders and the community to develop tourism in Aceh. Tourism in Aceh is required to produce appropriate and applicable strategies and policy directions to develop these various tourism potentials (disbudpar.acehprov).

This problem is a challenge experienced by the Aceh government, especially for the Aceh Culture and Tourism Office, because it is one of the priority programs that has been signed in the Helsinki memorandum of understanding or called the Helsinki MoU. These tourism developments support the progress of Aceh Province to improve the economy. Through "The Light of Aceh," the Disbudpar of Aceh Province promotes tourism in Aceh, including marine, nature, religion, history, and culinary tourism, which are incorporated in halal tourism, and with dignity. This branding, promoted through social media, makes it easier for foreign and domestic tourists to visit Aceh.

The development of tourism through social media has been carried out by the culture and tourism office of Aceh Province through the Branding of "The Light of Aceh," which is a joint movement to build the Aceh tourism industry through the spirit of Branding "The Light of Aceh", the aim is to increase tourism development and promote Aceh tourism. This study focuses on the Branding Strategy of "The Light of Aceh" through E-Tourism in Sustainable Tourism Development in Aceh Province through social media and the Aceh Disbudpar website. It will have a good impact on the community's economy and during the COVID-19 pandemic. This research is useful for facilitating tourist visitors to Aceh, promoting their tourism potential, and impacting Aceh's original income. Social media in the current era plays an important role in tourism. The internet 
has become one of the solutions offered to facilitate the development of tourism in Indonesia, especially in the province of Aceh. Through social media, many things can be accessed easily and used by most people in the world. Dissemination of information regarding tourism development should be accessible. Therefore, the authors want to analyze the sustainable tourism development strategy in Aceh Province seen from the website Acehtourism.travel, Aceh tourism applications and Twitter managed by the Aceh government and the Acehnese people.

\section{RESEARCH METHOD}

This research used qualitative and descriptive methods. Qualitative research is a type of research whose findings are not obtained through statistical procedures or other calculation forms. According to the researcher's perspective, it understands and interprets the meaning of an event of human behavior interaction in certain situations (Gunawan, 2016). This study used a descriptive qualitative approach by analyzing social media content (Twitter, government agency websites, and online news). The authors used qualitative and descriptive methods because his research focuses on developing sustainable tourism through social media in Aceh Province: Branding "The Light of Aceh". The subjects in this study were institutions involved in tourism, such as the Aceh Culture and Tourism Office (Disbudpar), the Twitter Admin of @wisataacehID, and the Tourism Ambassador Community in Aceh. The scope of the variables is information from social media, the Aceh Disbudpar website, and the Aceh Tourism Application.

This research occurred in Aceh Province because Aceh's large tourism potential will greatly benefit the community's welfare and progress. Following up on the Aceh Government's Vision, "A dignified, prosperous, just and independent Aceh based on the UUPA as a form of the Helsinki MoU", there are 3 (three) priority programs out of 10 (ten) Aceh Development Priority Programs for culture and tourism towards a dignified Acehnese society, prosperous, just and independent. This type of data used primary data involving original document data collected from actual situations where the event occurred. Sources of data were obtained directly by analyzing social media. The primary data came from online media related to sustainable tourism development strategies in Aceh Province. Secondary data is obtained indirectly by researchers from various books, laws and regulations, journals, publications from related organizations or institutions. Data collection techniques came through interviews, capturing data taken through social media and documentation and using Nvivo 12 plus analysis through crosstab using charts and sociogram features.

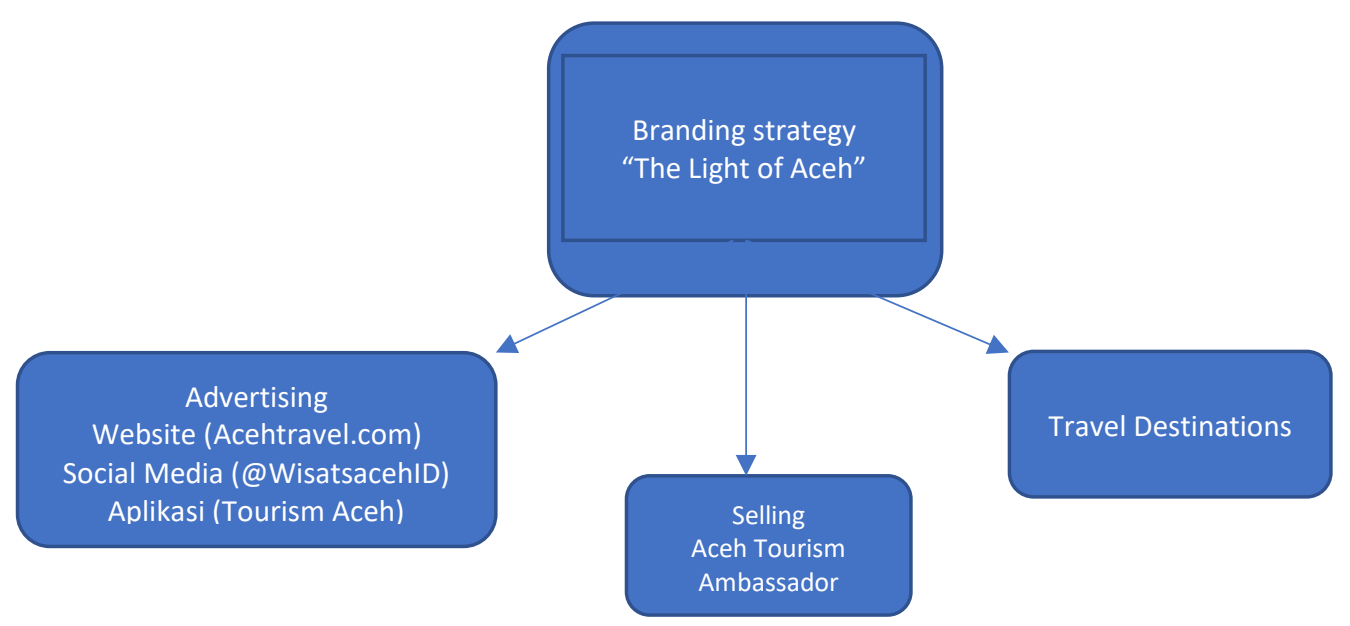

Figure 3. Theoretical Framework 


\section{City Branding Theory}

(Rahmanto, 2020), in City Branding theory, stated three concepts, identity, image, and communication. Identity (brand identity) is what the sender does. Image (brand image) is a real image built in the recipient's mind (receiver). Communication is how the information will be built through branding to be accepted and easy for visitors.

\section{RESULT AND DICUSSION}

Branding is the idea and process of identifying, shaping and promoting a certain image of a city that makes the city good in the eyes of stakeholders, easy to remember, and has advantages (Rahmanto, 2020). In this case, "The Light of Aceh" is the branding for Aceh tourism. Aceh province has much tourism potential from marine tourism, culinary, religion, nature, and history. The amount of tourism in Aceh is one solution in increasing the economy through the tourism sector. Through this branding, the Aceh government has its vision and mission to develop and promote Aceh tourism. The implementation of tourism in Banda Aceh City is carried out by upholding cultural and religious values (Irwansyah \& Zaenuri, 2021).

(Rahmanto, 2020) City Branding theory has three concepts, identity, image, and communication. Identity (brand identity) is what the sender does. Image (brand image) is a real image built in the recipient's mind (receiver). Communication is how the information will be built through branding to be accepted and easy for visitors. According to Ramadhani Sulaiman, as the head of tourism promotion and marketing, he explained that the City Branding theory is closely related and in line with what has been done to promote Aceh tourism through "The Light of Aceh" branding. This concept is one of the guidelines for the advancement of tourism in Aceh, one of which we can explain that where the identity is How the strategy of the Aceh Disbudpar as a sender of information to find ways how to make an interesting thing so that foreign tourists or local tourists are interested in visiting Aceh with a variety of tours or destinations that are widely available in Aceh Province, then the second concept is this image or brand is a real image that is awakened in the minds of foreign tourists and local tourists is. The goal is to create a good image. The third concept of communication is how the sender of information makes good communication to foreign tourists and local tourists. The Disbudpar of Aceh Province through the website Acehtourism.travel provides much information about tourism in Aceh Province. Through @Acehtourism, @wisataacehid, and many other Twitter accounts, promotions through social media and online media also develop tourism in Aceh Province. In the 4.0 era, the internet is currently one of the most strategic digital platforms that everyone can access quickly and easily.

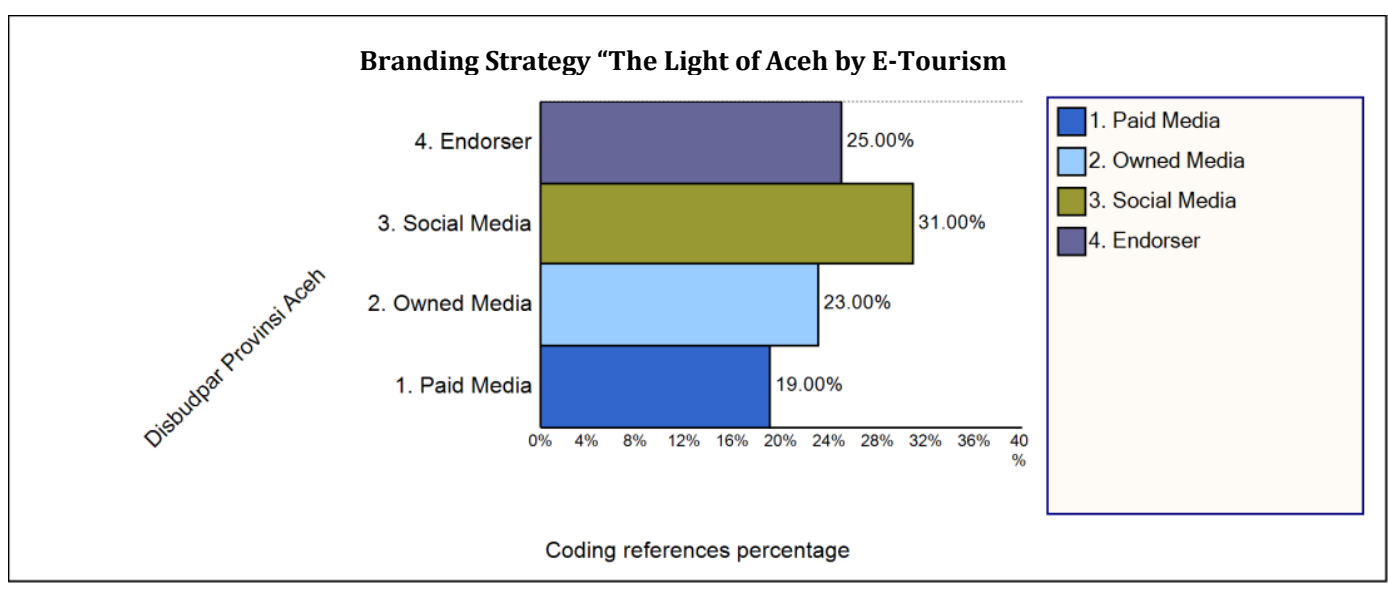

Figure 4. Branding Strategy “The Light of Aceh by E-Tourism 
According figure 4. to the Nvivo 12 plus analysis using the crosstab chart feature, promoting tourism in Aceh Province using the Branding strategy "The Light of Aceh" through E-Tourism produced various percentages. According to Mr. Ramadhani Sulaiman, as head of tourism promotion and marketing in Aceh Province, "The Light of Aceh" through E-Tourism in sustainable tourism development used four strategies: POSE (Paid Media, Owned Media, Social Media, and Endorser). The first strategy is Paid Media with a percentage of $19.00 \%$, then Owned Media with $23 \%$, Social Media with a percentage of $31 \%$, and the last is Endorser with a percentage of $25 \%$. Of the four strategies, the highest percentage is the tourism promotion strategy through social media because social media is the most strategic, easy and accessible digital platform for visitors at any time. Then, the second is through an endorser. These four strategies are the most important in promoting tourism in Aceh Province through E-Tourism. (Van \& Hieu, 2020) Branding plays a role in shaping customer search behavior which means personalized brands effectively help travel businesses find potential customers and develop customized services to maintain business profits.

Paid Media collaborates with electronic printing paid media to spread tourism promotion in Aceh and whatever we do to promote the best tourism to attract foreign and local tourists. Then, Owned Media is media owned by the Disbudpar of Aceh Province's website, Acehtourism.travel. It contains all tourism-based activities, attractions, transportation, tourist destinations in Aceh Province and Acehnese culinary specialties. Third, Social Media affects the progress of tourism in Aceh. Social media such as YouTube, Facebook, Instagram, and Twitter will help do various publications, caption creation posts, and content materials. This method is effective, productive, and most strategic in promoting tourism in Aceh Province. The fourth is Endorser, a supporter or person involved in promoting tourism in Aceh. Disbudpar Aceh Province collaborates with all stakeholders, influencers, tourism ambassadors in Aceh, phenomenal Acehnese artists and the publication team, including Pesona Indonesia, also joined in internetbased communities and people who like tourism the impression a beautiful view of tourism in Aceh Province. Those are our four strategies in promoting Aceh. Here, the authors collaborated with millennials and the younger generation members of tourism promotion in Aceh through "The Light of Aceh".

Tourism marketing theory (Lumsdon, 1977) revealed 4 (four) elements: market, travel, destination, and marketing (Lumsdon, 1997). Mr. Ramadhani Sulaiman, as the head of promotion and marketing, explained that promoting and marketing Aceh through the Branding "The Light of Aceh" is necessary. The first element, the market, explains how to increase tourist visitors' attractiveness, one of which is through "The Light of Aceh". The second element, travel, is transportation to reach tourism places. A tourism destination must provide convenience and information about transportation. The third element, destination, is an offer or package of any tourist attractions available in Aceh Province accessed directly through the Aceh Province Disbudpar website, Acehtourism.travel can also be through the Aceh Tourism application which is available for download from the smartphone. The fourth is marketing to increase visitors. In this case, promotion is carried out through 4 strategies that the Disbudpar of Aceh Province has implemented, called POSE (Paid Media, Owned Media, Social Media, and Endorser).

The whole community well receives marketing and promotion of tourism. All visitors of foreign tourists and local tourists to Aceh will significantly increase the level of the economy in Aceh. From the last five years, foreign tourists and domestic tourists have increased significantly every year. In 2020, it decreased by $99 \%$ due to the spread of the Coronavirus from Wuhan, China. Therefore, the drastic decrease in the level of visitors to Aceh due to the closing of the entrance to Indonesia, especially in Aceh Province and we must build a good brand or image so that it has a positive impact on visitors who want to visit Aceh Province with the implementation of the new normal which requires compliance with health protocols. Through the new normal, we continue to develop tourism. The goal is to improve the economy and adopt the right health protocols. Social actors managing tourist objects must implement the new normal through health, cleanliness, security, and preservation. All must be healthy, safe and comfortable. The concept of tourists in the future must wear masks, maintain distance, and socialize through social media 
about health protocols to visit tourism places in Aceh. Thus, the community's economy through the tourism sector can support and encourage further development. With the cooperation between all district/city stakeholders, all existing agencies will help develop these destinations.

(Schmidt \& Uriely, 2019) is currently considering the development of tourism in the suburbs through the empowerment of local communities. In tourism research, the importance of empowerment is discussed in the conceptual framework of CBT, which is defined as a tradition in sustainable tourism. (Yumna \& Conscience, 2019) The development of digital tourism in several areas has been able to keep up with the times and meet market demand. (Seetanah et al., 2019) The results showed that air access liberalization had made a positive contribution to the number of tourist arrivals in both the short and long term, although to a lesser extent than other classical determinants.

Regarding the priority of the tourism culture sector, empowering tourism is more about strengthening the preservation of tourism promotion while empowerment is about creating economic employment, creating a budget that focuses more on tourism culture, and the second is the preservation sector for its maintenance. New destinations can connect communities and the younger generation through tourist attractions. The facilities offered for foreign tourists are the facilities found in tourism places, then there is a money changer or souvenir to keep as a souvenir for foreign and domestic tourists. The tourist attraction is one of the events to attract foreign and domestic tourists.

\section{Advertising through Twitter @wisataacehID and @acehtourism}

Social media is influential enough to make it easier for people to interact with each other, and its practical nature and easily accessible to its users (Annisa Senova, 2016). In its development, Twitter is used as a medium for promoting and marketing goods and services produced by individuals and companies (Susanti \& Erwina, 2020). In this case, tourism in Aceh province also promotes tourism through social media, one of which is Twitter. In the life of industry 4.0 today, social media is a strategic digital platform to promote tourism and information is received more quickly by the wider community. The @wisataacehID Twitter account is used to explore various destinations in Aceh Province. The account was created by an Acehnese named Khairul Mubaraq. The Twitter account is currently collaborating with Disbudpar Aceh in promoting tourism in Aceh. Through this Twitter account, more tourist destinations in Aceh are being explored. However, some new tourist destinations are still lacking from inadequate facilities and infrastructure not to access them. However, this issue is also a challenge and aspiration for the Aceh government in building better infrastructure. Below are the analysis results using the Nvivo 12 plus analysis technique through crosstab and the chat feature. Through this Sociogram, various other accounts respond to the @wisataacehID Twitter account to promote tourism. The Sociogram of the @wisataacehID Twitter account, which displays the central out-of-degree point for the Twitter account, will clarify all the exit lines made on the network and create good cooperation in promoting tourism which is channeled in the most central place or center through the @wisataacehID Twitter account and many reposted by another Twitter account in promoting Aceh tourism. With this social network, it is easier to find ideas about Aceh tourism before visiting social media accounts such as Twitter for tourists from abroad and domestic tourists because everyone uses social media, including tourists searching for tourist attractions.

In this case, the Acehnese people also promote and develop tourism in Aceh Province, with many pictures and tweets reposted by other accounts. This situation is influential in promoting tourism through Twitter as a digital platform in Aceh Province. This social media is a place for regional promotion because it is easier, effective, strategic and can improve regional economic development and community sustainability in the future. 
Table 1. Twitter Accounts in Promoting Aceh Tourism (processed by researchers, 2021)

\section{Twitter accounts promoting tourism in Twitter Accounts Providing Information} Aceh Province

\begin{tabular}{|c|c|}
\hline Icehtourism & \\
\hline ienpiaceh & \\
\hline ndtravel & \\
\hline Iceh_disbudpar & \\
\hline ieputaraceh & @wisataacehID \\
\hline Iumasaceh & \\
\hline @Iloveaceh & \\
\hline @Dubesaustralia & \\
\hline @Modern_models & \\
\hline @Acehtravel & \\
\hline @Tourismaceh & \\
\hline
\end{tabular}

Media such as Facebook, Instagram, Twitter, YouTube are used in the dissemination of information which is possible to explain and promote various information (Mardhiyani, 2020). One of them is that the Disbudpar of Aceh Province currently uses @acehtourism to promote tourism in Aceh.

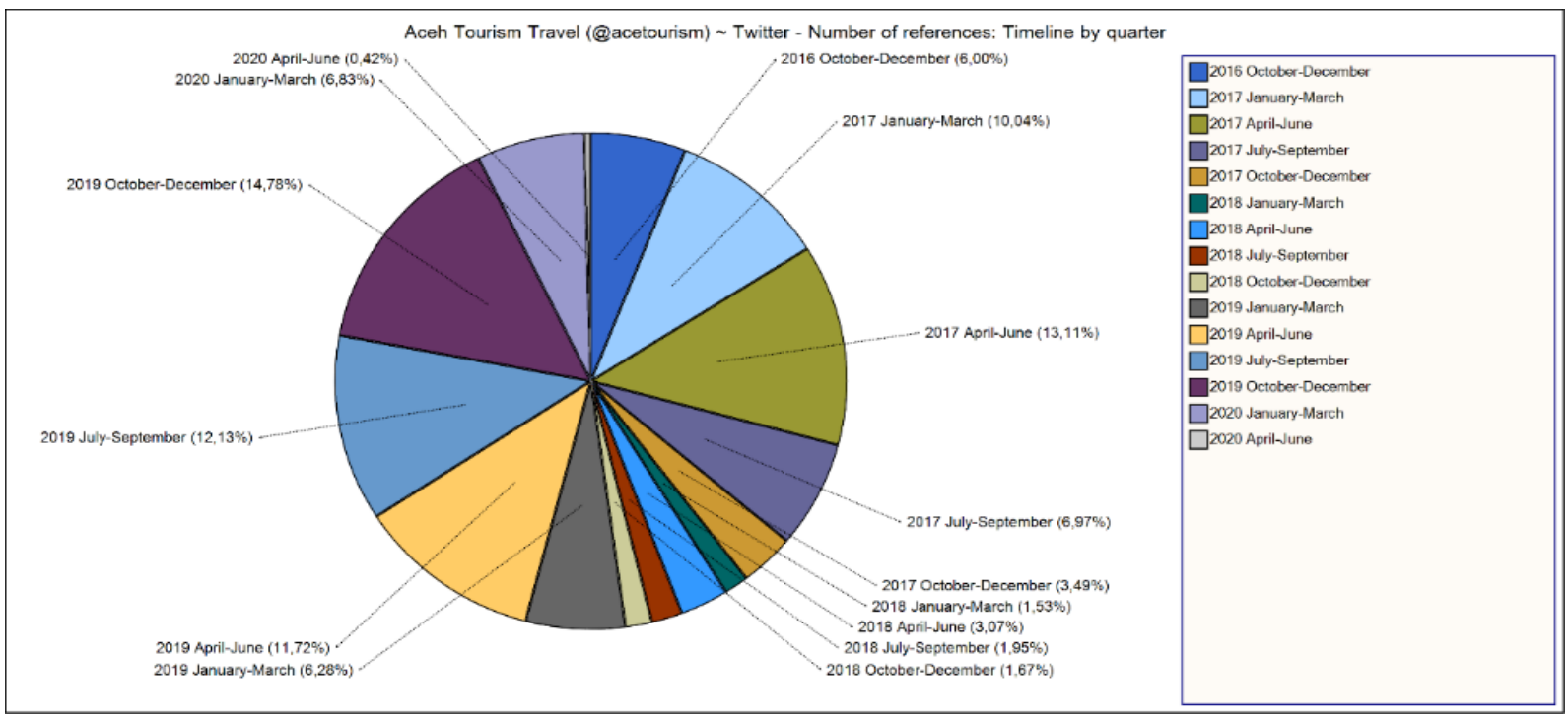

Figure 5. Analysis Results of Nvivo 12 Plus through Twitter, Chart Features (processed by researchers, 2021)

Figure 5 shows that the @Acehtourism Twitter account belonging to the Disbudpar of Aceh Province promotes tourism in 2016-2020. In 2019, October-December is the highest year on the @acehtourism in promoting tourism in Aceh compared to previous years with $14.78 \%$. This Twitter account experiences a decline in 2020 due to the outbreak of the COVID-19. Indonesia had to close its entrance from air, sea, and land transportation. In 2018, Twitter's activity in promoting tourism is not balanced, and no increase from January to December. In 2017, @acehtourism is also active in April-June with 13.11\%. In 2016, the activeness of the @Acehtourism Twitter account has not shown any progress. @Acehtourism also strongly supports the development of Aceh tourism. Through Twitter, @acehtourism offers foreign and domestic tourists to participate and exchange information about tourism through social media. 
In other words, the government has succeeded in implementing and promoting tourism using ETourism in Aceh Province.

\section{Advertising through the Aceh Tourism Application}

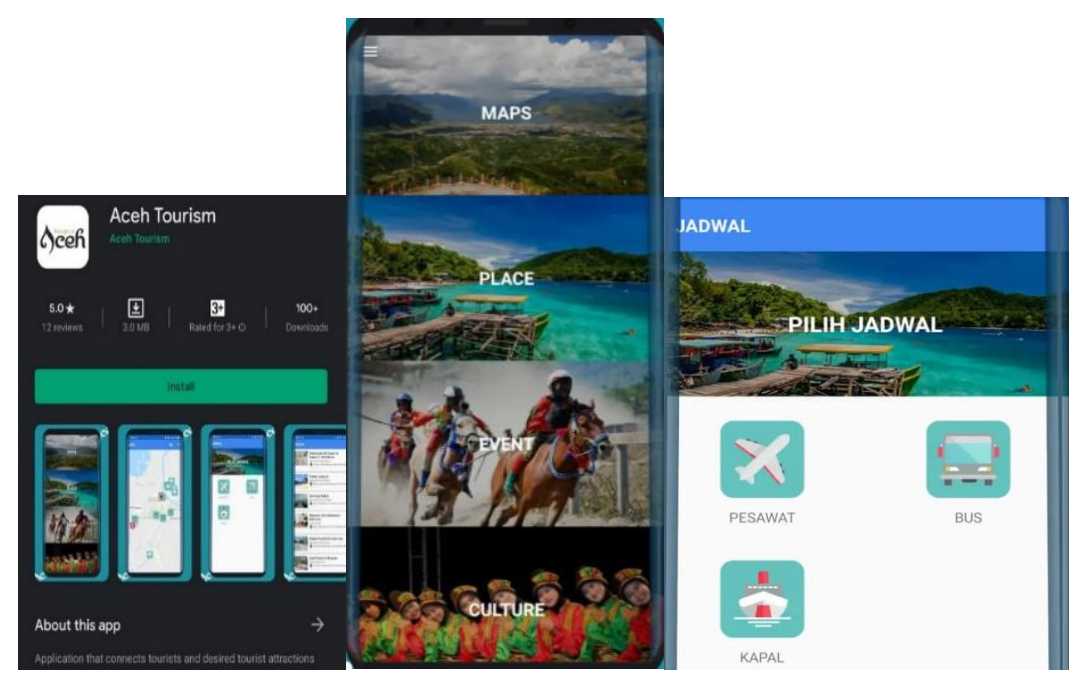

Figure 6. Application Tourism Aceh, Captured Windows 10

Figure 6 shows that the Aceh tourism application is available for download to allow tourists access all information about tourism in Aceh Province. This artificial intelligence can make the tourism sector in Aceh Province better. In the application, there are various options such as tourist destinations, Acehnese cuisine, Acehnese culture, and events every year. (Artementko et al., 2017) Information and technology intelligence development in implementing a tourism recommendation system is useful for advancing and developing sustainable tourism. The ETourism application is an Artificial Intelligence in today's modern life. This application is designed to make it easier for foreign and domestic tourists to travel to Aceh Province. (Mangkey et al., 2016) E-Tourism is intended to access information and a place to manage data about tourist objects and events. In the application, there are Maps to make it easier for visitors to travel to the tour they want to go to, then there is an explanation of the menu air, land, and sea transportation, events held annually, as well as Aceh's customs and culture. This application should also have a continuation.

\section{Selling through the Aceh Tourism Ambassador Community}

According to (Dai et al., 2019), marketing should more effectively focus on and promote 'local flavor' experiences. Tourism in Aceh is also seen from the characteristics of the Acehnese people themselves. Promoting tourism in Aceh also involves all Acehnese people, where the Acehnese people promote all tourism in Aceh through social media such as Facebook, Instagram, Twitter and others. Then, many accounts such as @wisataaceh, @tengokaceh, @pariwisataaceh, @acehtourismtravel help promoting. Then, many other social media accounts also promote Aceh tourism because the internet network is also more accessible and strategic when the promotion is through social media and can be developed and accessed more by the whole community and foreign tourists and local tourists visit Aceh. Through the community forum for tourism ambassadors and influencers, it is one of the places where tourism promotion is developed when there are negative issues regarding tourism in Aceh, which can be monitored by tourism ambassador communities in Aceh who are members and involved in tourism promotion in Aceh Province. Branding is very important to build a positive image for an area in promoting its tourism. With a community of tourism ambassadors, influencers and collaborating with the 
young millennial generation, the goal is to advance the economy through the tourism sector in Aceh Province.

The tourism ambassador community is also incorporated in the charming tourism of Aceh, which is the branding of Aceh tourism. For example, during the festival organized by the Disbudpar of Aceh Province, the tourism ambassadors conducted socialization to the public and tourist visitors to be aware of tourism, and tourism ambassadors made flyers that would be distributed to the public, foreign and domestic visitors. By taking advantage of social media, promoters can create content related to tourism in Aceh. The tourists can post photos while visiting destinations and share information with significant others. This method could be the right way to promote tourism.

Now, Aceh has many promoters who help the government promote tourism in Aceh and bring in many foreign and domestic tourists who want to visit Aceh. Existing support for the development and promotion of Aceh tourism in a short frame in the long jump is good cooperation, of course with travel entrepreneurs, souvenirs, and related to leading tourism in Aceh, which is the center of attention of tourists who will attend Banda Aceh City in particular. In visiting these tourist attractions, there are many such as the Aceh Tsunami Museum, Baiturrahman Grand Mosque and PLTD floating ships which were silent witnesses of the 2004 tsunami.

\section{Travel Destination}

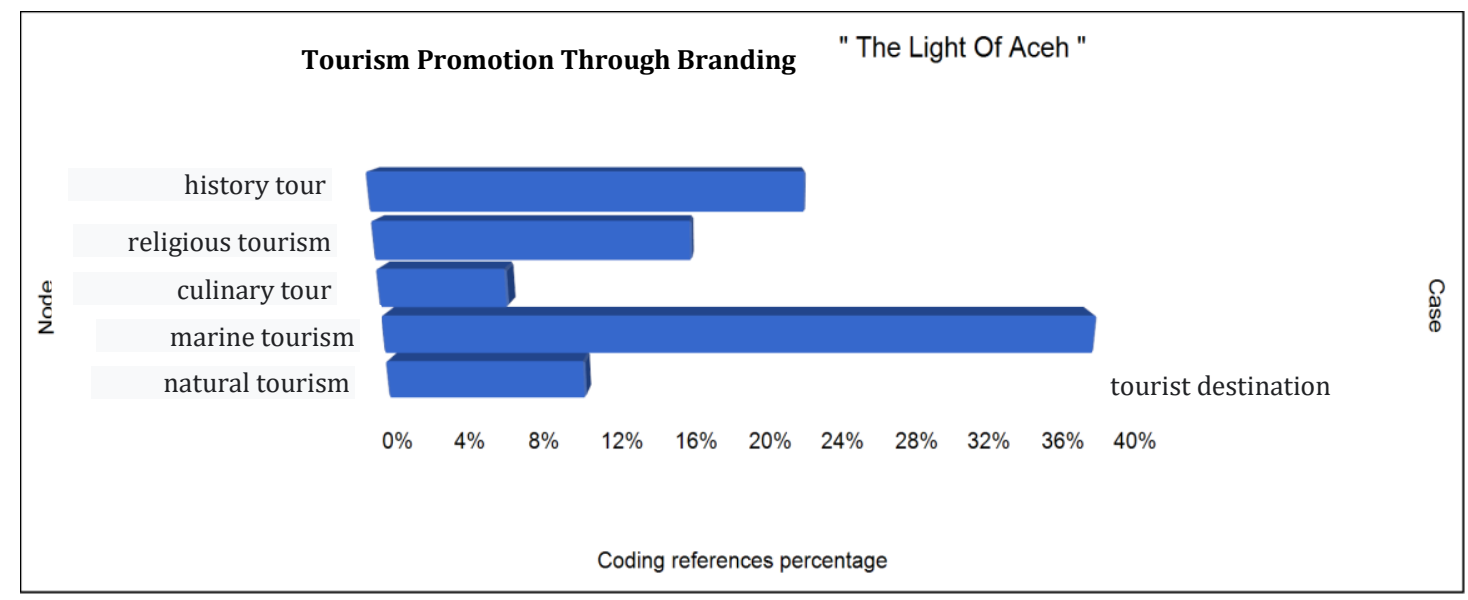

Figure 7. Analysis Results of Nvivo 12 Plus Via Twitter, Chart Features

(processed by researchers, 2021)

Figure 7 shows that the most popular tourist destinations for foreign and domestic tourists are marine tourism, with 39\% the highest percentage. As a marine tourism destination, Sabang has become a favorite tourist icon. The view of the Sabang beach and the beauty of coral reefs and ornamental fish are spots that become the attraction of every foreign and domestic tourist. Gapang Beach, Iboh Beach, Rubiah Beach, and Anoi Itam are spots to see the underwater beauty. Various fish species in the sea inhabit coral reefs and ornamental fish that adorn every beach in Sabang. Sabang is located at the end of Aceh Province, often called Pulau Weh. Sabang is one of the gateways to Indonesia, which has maritime territorial boundaries with India and Thailand. Sabang is also the kilometer of Indonesia.

Then, according to the Nvivo 12 plus analysis results, the second is historical tourism with a $23 \%$ percentage. Aceh, apart from being famous for its marine tourism, is also famous for its history. The most interested by visitors is the Tsunami Museum. The Aceh Tsunami Museum is a history whose momentum remembers all Acehnese people with the earthquake and tsunami disaster on December 26, 2004. All relics found after the disaster are stored in the Tsunami museum. This tsunami is not only an issue and sad news in Indonesia, but this sad news has reached all corners of other countries. This museum was built by the United Nations (United 
Nations). This museum is also used as an educational center for natural disaster protection if an earthquake and tsunami occur in the area and has become an icon of Aceh's strength in dealing with the earthquake and tsunami several years ago. The third is religious tourism, which amounts to $17 \%$ of the percentage results. Aceh is very famous for its Islamic law until Aceh is nicknamed the Veranda of Mecca. The building, which was once the mosque of the Aceh Sultanate, was built by Sultan Iskandar Muda Mahkota Alam in 1022 h $1612 \mathrm{~m}$. Baiturrahman Grand Mosque is a mosque located in the center of Banda Aceh City, Aceh Province, which symbolizes religion and culture, the spirit of struggle and nationalism of the Acehnese people. The splendor of the mosque building is also an attraction for tourists, especially for tourists who are looking for religious nuances. The Baiturrahman Grand Mosque has a wide plain and an umbrella right in the Nabawi Mosque in Medina.

Fourth is nature tourism which the percentage is $11 \%$. Natural tourist destinations in Central Aceh, precisely in Takengon City, can be the country of a thousand hills because hills surround it and the air is very cold. Pantan Terong is one of the natural destinations in Aceh, which is located on the top of a hill in the Gayo Tekengon plateau, Bebesen District, Central Aceh Regency. This hill is located at an altitude of more than 1,350 meters above sea level. From this place, you can see the capital city of Takengon and the freshwater lake as a whole and the Bebangka Horse Racing field in Pegasing District, Rembele airport at the remodeling intersection flanked and surrounded by very beautiful mountain ridges. The fifth is culinary tourism, whose percentage is $7 \%$ Aceh. Besides being famous for various marine, natural, historical, and religious tourism destinations, it also has distinctive culinary delights, such as gayo coffee, Acehnese noodles, curry meat, and other things. Aceh is one of the provinces in Indonesia which is very rich in spices. Past commercial relations between India and Aceh had an impact on social interactions. The social interaction is the influence of Indian culture in the culinary treasures of the archipelago and the introduction of new cooking spices.

\section{Inhibiting Factors in Tourism Development}

Figure 8 shows that the inhibiting factors in tourism development are infrastructure, social conditions of the community, and natural resources. These three factors are the obstacles that most often appear in people's assumptions and are visible when the tourism actor visits the location of tourism destinations in Aceh Province. The most important inhibiting factor is human resources with a $40 \%$ percentage. The second is infrastructure with a $34 \%$ percentage. The third is the social conditions of the community with a $26 \%$ percentage.

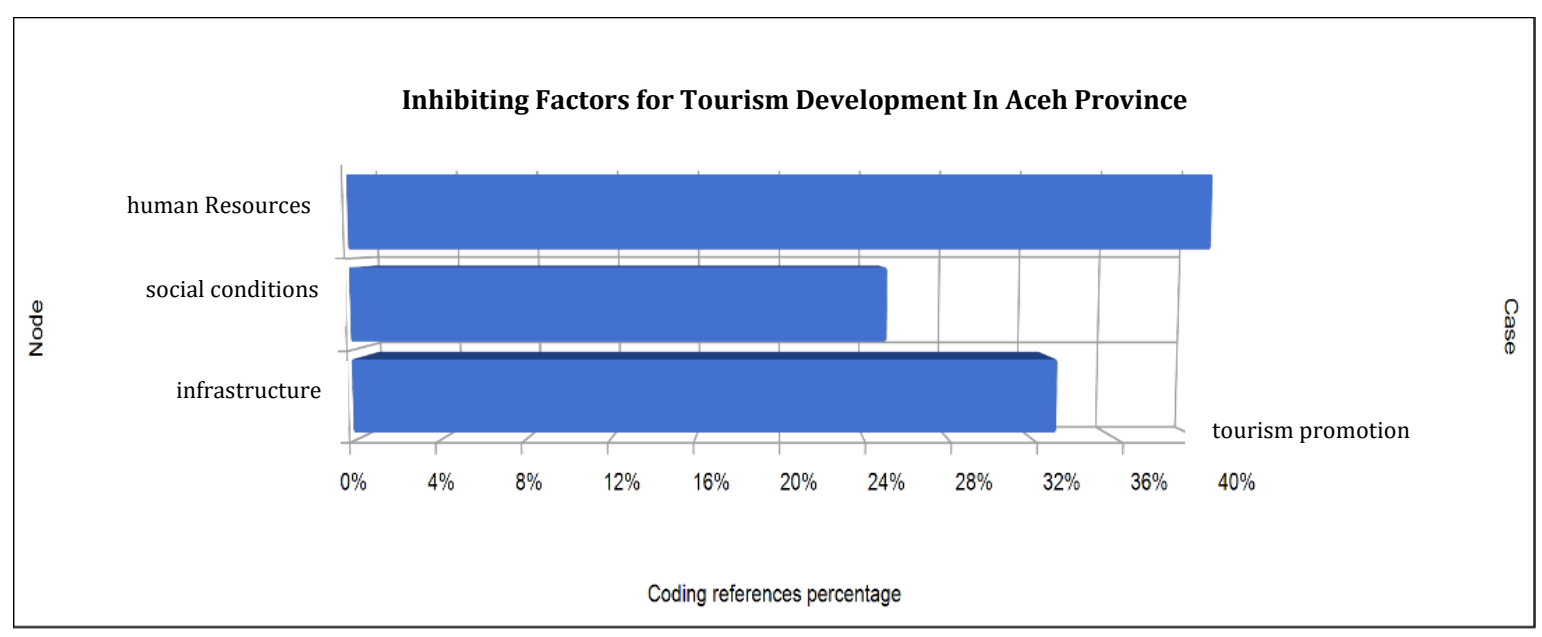

Figure 8: Nvivo 12 Plus Analysis Results, Chart Features

(Processed by Researchers, 2021) 


\section{CONCLUSION}

The results indicated the Branding strategy of "The Light of Aceh" through E-Tourism in sustainable tourism development using four strategies, POSE (Paid Media, Owned Media, Social Media, and Endorser). Of the four strategies, the highest percentage was the tourism promotion strategy through social media because social media was the most strategic, easy and accessible digital platform for visitors at any time. The whole community received marketing and promotion of tourism. All visitors of foreign tourists and local tourists to Aceh would significantly increase the level of the economy in Aceh. From the last five years, foreign tourists and domestic tourists have increased significantly every year drastically, and in 2020, it decreased by $99 \%$ due to the spread of the Coronavirus from Wuhan, China.

The inhibiting factors of human resources are still minimal, while infrastructure has not been managed properly, and social conditions of the community become an obstacle when Disbudpar Aceh Province has not provided information on how to adapt to foreign and domestic tourists. Therefore, hospitality is vital to support tourism actors whether or not to return to Aceh to travel, then the level of security in Aceh needs to be socialized through various online and social media. So far, the "The Light of Aceh" branding has been quite effective in boosting the visits of foreign tourists and domestic tourists who are promoted through social media.

These inhibiting factors can have quick resolutions to run and develop more optimally through tourism promotion and tourism development in Aceh Province. The limitation of this research is that it only discusses the Branding Strategy "The Light of Aceh" through E-Tourism in Sustainable Tourism Development in Aceh Province and the scope of research data only specifically discusses tourism in Aceh Province and only a few tourist destinations are shown in this study. Future research should conduct more research that discusses the existing tourist destinations in Aceh Province or strategies in promoting tourism in other provinces because Indonesia is rich in tourism and will present many new strategies.

\section{REFERENCE}

Annisa Senova. (2016). LITERASI MEDIA SEBAGAI STRATEGI KOMUNIKASI TIM SUKSES RELAWAN PEMENANGAN PEMILIHAN PRESIDEN Jokowi JK DI BANDUNG. Jurnal Kajian Komunikasi, 4(2), 142-153. https://doi.org/10.24198/jkk.vol4n2.3

Artemenko, O., Kunanets, O., \& Pasichnyk, V. (2017). E-tourism recommender systems : a survey and development perspectives. Econtechmod. An International Quarterly Journal, 6(2), 9196.

Bhatta, K., \& Ohe, Y. (2019). Farmers' willingness to establish community-based agritourism: evidence from Phikuri village, Nepal. International Journal of Tourism Sciences, 19(2), 128144. https://doi.org/10.1080/15980634.2019.1621536

Dai, T., Hein, C., \& Zhang, T. (2019). Understanding how Amsterdam City tourism marketing addresses cruise tourists' motivations regarding culture. Tourism Management Perspectives, 29(October 2018), 157-165. https://doi.org/10.1016/j.tmp.2018.12.001

Datya, A. I. (2019). Implementasi Elemen User Interactive ( UI ) Dan User Experience ( UI ) Dalam Perancangan Antarmuka Sistem Informasi E-Tourism Di Bali Berbasis Web. 153-160. https://www.jurnal.undhirabali.ac.id/index.php/sintesa/article/view/829/726

Gunawan, I. (2016). KUALITATIF Imam Gunawan. Pendidikan, 27.

Irwansyah, I., \& Zaenuri, M. (2021). Wisata Halal: Strategi dan Implementasinya di Kota Banda 
Aceh. Journal of Governance and ..., 2(1). https://doi.org/10.24815/gaspol.v2i1.

Mangkey, H., Rindengan, Y., Sc, S. T. M. M. M., Tulenan, V., Ti, S. K. M., \& Ratulangi, U. S. (2016). ETourism Kota Tomohon Menggunakan Html5. Jurnal Teknik Elektro Dan Komputer, 5(4), 60-69. https://doi.org/10.35793/jtek.5.4.2016.13673

Mardhiyani, N. L. (2020). Tourism 4.0: Strategi komunikasi pemasaran pariwisata kota semarang. Jurnal Kajian Media, 4(1), 40-52. https://doi.org/10.25139/jkm.v4i1.2384

Rahmanto, A. (2020). City Branding Strategi Komunikasi dalam Memasarkan Potensi Daerah (R. T. Kusuma \& K. Sukmawati (eds.); Cetakan Pe). Empat Dua Media.

Rizki Wahyudi, Ema Utami, M. R. A. (2016). Sistem Pakar E-Tourism Pada Dinas Pariwisata D.I.Y Menggunakan Metode Forward Chaining. Jurnal Ilmiah DASI, 16(4), 1-14.

Schmidt, J., \& Uriely, N. (2019). Tourism development and the empowerment of local communities: The case of Mitzpe Ramon, a peripheral town in the Israeli Negev Desert. Journal of Sustainable Tourism, 27(6), 805-825. https://doi.org/10.1080/09669582.2018.1515952

Seetanah, B., Sannassee, R. V., Teeroovengadum, V., \& Nunkoo, R. (2019). Air access liberalization, marketing promotion and tourism development. International Journal of Tourism Research, 21(1), 76-86. https://doi.org/10.1002/jtr.2242

Susanti, S., \& Erwina, W. (2020). Pesan Promosi Program Televisi dalam Akun Twitter @netmediatama. Komuniti: Jurnal Komunikasi Dan Teknologi Informasi, 12(1), 1-10. https://doi.org/10.23917/komuniti.v12i1.9634

Van, H. T., \& Hieu, V. M. (2020). Travel Branding in Tourism 4.0: Case Study Vietnam Travel. Journal of Asian and African Studies, 55(6), 896-909. https://doi.org/10.1177/0021909620935428

Yumna, A., \& Nurani, F. (2019). Pengembangan Digital Tourism Sebagai Upaya Media Promosi ( Studi pada Pantai Balekambang , Malang ). 1-5.

Zaenuri, M., Hakim, A. R., \& Fridayani, H. D. (2019). Collaborative Governance In Managing Educative Tourism Of Jogja Exotarium In Sleman Regency 2019. Journal of Governance and Public Policy, 6(2). https://doi.org/10.18196/jgpp.62115 